\title{
Dziedzictwo geologiczne
}

\section{Jan Urban ${ }^{1}$, Piotr Migoń ${ }^{2}$, Barbara Radwanek-Bąk ${ }^{3}$}

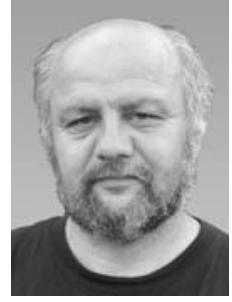

J. Urban

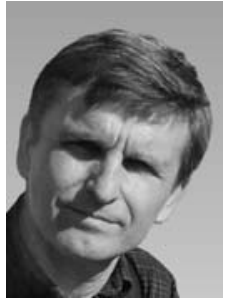

P. Migoń

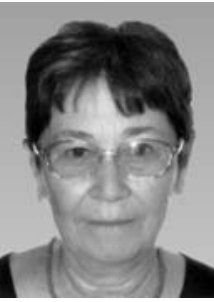

B. Radwanek- Bak

Geological heritage. Prz. Geol., 69: 16-20; doi: 10.7306/2021.1

A b s tract. Geoheritage (geological heritage), that is tangible evidence of geological past and contemporary processes, is increasingly recognized as a valuable component of environment, worth conservation and popularization. It comprises elements of Earth's geodiversity, which are significant for scientific, educational, cultural, ecological or aesthetic reasons. Among them, the key role is played by geosites, at which elements of geoheritage are best exposed and have the most evident value. Various classifications of geosites by the main theme have been proposed and various methods of evaluation of geosites exist, involving among others, assessment of their scientific importance, cultural/historical value, threats and educational opportunities. Geoheritage in a given place or area may have global, national, regional or local significance. Globally significant geoheritage is protected at UNESCO World Heritage properties and in UNESCO Global Geoparks. In Poland, geoheritage is protected in national and landscape parks, more than 110 nature reserves, more than 1600 nature monuments and more than 120 sites of special scientific interest (documentary sites). This paper opens a section of "Przeglad Geologiczny", in which representative geosites of Poland will be successively presented.

Keywords: geoheritage, geosites, geoconservation, geodiversity

Dziedzictwo geologiczne (geological heritage, geoheritage) to pojęcie, które $\mathrm{w}$ ostatnich latach stało się powszechne w słownikach geologicznych świata i zyskało znaczenie w działaniach służb geologicznych, organów ochrony przyrody różnych krajów oraz organizacji pozarządowych i stowarzyszeń naukowych. Termin ten pojawił się po raz pierwszy w Międzynarodowej deklaracji praw pamieci Ziemi (International Declaration of the Rights of the Memory of the Earth), przyjętej podczas I Międzynarodowego Sympozjum Ochrony Dziedzictwa Geologicznego, które odbyło się w Digne les Bains, we
Francji, w 1991 r. (Martini, 1994; Kasprzak, Skoczylas, 1994). Sygnatariuszem tej deklaracji była m.in. prof. Zofia Alexandrowicz, główna propagatorka idei ochrony dziedzictwa geologicznego w Polsce.

Pierwsze angielskojęzyczne definicje dziedzictwa geologicznego pojawiły się jeszcze w końcu XX w., na początku XXI w. funkcjonowało zaś już ich wiele-zostały one zebrane w publikacjach Dingwall i in. (2005) oraz Brocx i Semeniuk (2007). Wszystkie są do siebie bardzo podobne, różnią się tylko szczegółami. Definicja opublikowana w ostatnich dniach, która stosunkowo wszechstron-

\footnotetext{
${ }^{1}$ Instytut Ochrony Przyrody Polskiej Akademii Nauk, al. Adama Mickiewicza 33, 31-120 Kraków; urban@iop.krakow.pl

${ }^{2}$ Instytut Geografii i Rozwoju Regionalnego, Uniwersytet Wrocławski, pl. Uniwersytecki 1, 50-137 Wrocław; piotr.migon@uwr.edu.pl

${ }^{3}$ Instytut Gospodarki Surowcami Mineralnymi i Energią PAN, ul. Wybickiego 7a, 31-261 Kraków; brad@min-pan.krakow.pl
} 
nie uwzględnia aspekty zagadnienia, brzmi w oryginale następująco: Geoheritage comprises those elements and features of the Earth's geodiversity, either singly or in combination, that are considered to have significant value for intrinsic, scientific, educational, cultural, spiritual, aesthetic, ecological or ecosystem reasons and therefore deserve conservation (Crofts i in., 2020). W odróżnieniu od wcześniejszych definicji ta ostatnia podkreśla konieczność ochrony dziedzictwa geologicznego.

W publikacjach polskojęzycznych termin dziedzictwo geologiczne (niekiedy w formie geodziedzictwo, czy dziedzictwo Ziemi) pojawiał się dotąd rzadko (Kasprzak, Skoczylas, 1994; Rubinowski, 1994; Alexandrowicz, 2003, 2007; Migoń, 2008, 2012; Chybiorz i in., 2015; Chybiorz, Kowalska, 2017). Istnieją dwie polskie definicje tego pojęcia. Z. Alexandrowicz (2007) definiuje je jako składniki przyrodniczej georóżnorodności, które maja znaczaca wartość dla ludzi, badań naukowych, edukacji, estetyki, inspiracji, kulturalnego rozwoju oraz miejsc ważnych ze względów społecznych. Druga definicja jest nieco bardziej szczegółowa i pomaga odróżnić ten termin od innego ważnego pojęcia, które pojawiło się w ciagu ostatnich 30 lat - tj. georóżnorodności. Brzmi ona (Urban i in., 2020): dziedzictwo geologiczne to abiotyczne elementy przyrodyfragmenty skorupy ziemskiej, jej rzeźba oraz procesy kształtujace Ziemię, które umożliwiaja naukowa rekonstrukcje dziejów Ziemi i życia na niej oraz zrozumienie kształtujacych ja procesów, ale także elementy majace istotne znaczenie dla kultury $i$ życia intelektualnego człowieka. Dziedzictwem geologicznym są w świetle tych definicji struktury oraz profile geologiczne, skały i minerały, formy rzeźby terenu oraz inne zjawiska i procesy, które wspólnie ilustrują budowę Ziemi, dokumentują jej przeszłość i ewolucję życia, a także współczesne przemiany środowiska naszego globu (Wimbledon i in., 2001; Brocx, Semeniuk, 2007; Wimbledon, Smith-Meyer, 2012). Oprócz aspektu czysto naukowego, w pojęciu dziedzictwa geologicznego bardzo istotny jest aspekt kulturowy oraz funkcje edukacyjne, wskazujące na związki człowieka - historyczne i współczesne - z abiotyczną częścią ekosystemu (czyli tzw. Świadczenia geosystemowe - geosystem services, abiotic natural capital; Gray, 2013; Brilha i in., 2018). W aspekcie kulturowym mieści się m.in. istotne znaczenie krajobrazu oraz pojedynczych obiektów abiotycznych w świadomości społeczeństw, np. kamiennych budowli lub rzeźb, ale także jaskiń zamieszkiwanych w okresie paleolitu. Natomiast znaczenie edukacyjne dziedzictwa geologicznego polega na uświadomieniu społeczeństwu, jak wielką rolę w historycznym rozwoju ludzkości oraz we współczesnej gospodarce i środowisku życia człowieka odgrywają abiotyczne elementy przyrody, a także jak ważne dla rozwoju cywilizacji i gospodarki były i są nauki o Ziemi.

Słowo dziedzictwo (heritage), znane i używane w języku potocznym, bardzo dobrze określa podstawową cechę i znaczenie dziedzictwa geologicznego w systemie ekologiczno-ekonomiczno-społecznych zależności (tzw. systemie świadczeń ekosystemowych - ecosystem services; np. Solon i in., 2017). Dziedzictwo w powszechnym rozumieniu oznacza wartości lub dobra odziedziczone, pochodzące z przeszłości, które jednak należy zachować dla przyszłych pokoleń. Znaczenie dziedzictwa geologicznego dla nauki oraz dla edukacji społecznej, a także immanentne wartości tego dziedzictwa są motywacją do jego ochrony (Gray, 2013; Brilha $i$ in., 2018; Crofts $i$ in., 2020; Urban i in., 2020).
Stąd też zadaniem społeczeństw, w tym przede wszystkim organów decyzyjnych i wykonawczych (wśród tych ostatnich, zwłaszcza służb geologicznych i służb ochrony przyrody) w skali międzynarodowej, państwowej i regionalnej, ale także każdego członka społeczeństwa, jest ochrona dziedzictwa geologicznego. Oczywiście musi być ona poprzedzona odpowiednim rozpoznaniem tego dziedzictwa, czyli jego inwentaryzacją i waloryzacją.

Warto też zwrócić uwagę na powiązania pomiędzy dziedzictwem geologicznym, a innym bardzo ważnym i spopularyzowanym w ostatnim ćwierćwieczu pojęciem georóżnorodnością. Georóżnorodność, zdefiniowana w języku polskim przez Kozłowskiego i in. (2004) jako zróżnicowanie abiotycznych elementów przyrody, może być oceniana jakościowo oraz mierzona ilościowo dla danego obszaru (Gray, 2013; Zwoliński i in., 2018) i w tym sensie jest bardzo użytecznym, ale nie jedynym narzędziem wykorzystywanym do waloryzacji dziedzictwa geologicznego. Może być też przedmiotem ochrony, ale wówczas jest chroniona jako jedna $\mathrm{z}$ cech dziedzictwa geologicznego (Wyk de Vries i in., 2018; Crofts i in., 2020).

Podstawowymi elementami materialnego dziedzictwa geologicznego są stanowiska geologiczne, określane też jako geostanowiska (geosite, geomorphosite, geotope). Sa to ograniczone przestrzennie fragmenty skorupy ziemskiej lub jej powierzchni oraz efekty procesów zachodzących w tych miejscach kiedyś lub współcześnie - które jesteśmy w stanie zdefiniować (opisać jako integralne elementy) i określić ich wartość w pod względem dziedzictwa. Oprócz obiektów punktowych lub obszarów zwartych (o bardzo różnych wielkościach), stanowiskami geologicznymi mogą być obiekty podziemne (dostępne dla człowieka) czy też fragmenty den zbiorników wodnych (Wimbledon i in., 2001; Alexandrowicz, 2003, 2006, 2007; Reynard, 2004; Wimbledon, Smith-Meyer, 2012; Warowna $\mathrm{i}$ in., 2011; Brilha, 2018; Crofts i in., 2020). Przy czym w polskich realiach stanowisk geologicznych nie należy mylić ze stanowiskami dokumentacyjnymi, ten ostatni termin jest bowiem kategorią prawną - formą ochrony zdefiniowaną w ustawie o ochronie przyrody z 2004 r. Tak więc stanowisko geologiczne może, ale nie musi, być chronione jako stanowisko dokumentacyjne. Materialnymi elementami dziedzictwa są również obiekty ruchome, najczęściej wszelkiego rodzaju okazy, np. muzealne. Niektórzy autorzy (Wyk de Vries i in., 2018) podają też przykłady niematerialnego dziedzictwa geologicznego, takie jak pole magnetyczne Ziemi.

Proponowane w ostatnich latach metody waloryzacji stanowisk geologicznych mają znaczenie użytkowe i dotyczą różnych obszarów ich wykorzystania: naukowego, edukacyjnego lub geoturystyczno-rekreacyjnego (np. Brilha, 2018), choć w przypadku tych dwu ostatnich nie bardzo jest jasne, dlaczego stanowiska edukacyjne nie są utożsamiane ze stanowiskami geoturystycznymi. Dlatego przedstawiamy metodę waloryzacji zaproponowaną już kilkanaście lat temu przez Reynarda (2004), która uwzględnia wartości kompleksowo rozumianego dziedzictwa geologicznego stanowisk $\mathrm{z}$ zastosowaniem następujących kryteriów: integralność, reprezentatywność, unikatowość, czytelność naukowa, dostępność, podatność na zniszczenie, walory estetyczne i walory kulturalno-historyczne. Wśród ważnych kryteriów wymienia się też korelatywność (z innymi stanowiskami), której brak w klasyfikacji Reynarda (Wimbledon i in., 2001). Waloryzacja 
prowadzi do wyróżnienia stanowisk o znaczeniu globalnym, kontynentalnym (ponadregionalnym), regionalnym i lokalnym (Brocx, Semeniuk, 2007; Brilha, 2018). Polska lista stanowisk o ponadregionalnym znaczeniu, zaproponowana kilkanaście lat temu, liczy 175 stanowisk (Alexandrowicz, 2006). Część dziedzictwa geologicznego o globalnym znaczeniu jest chroniona $\mathrm{w}$ ramach Konwencji Światowego Dziedzictwa UNESCO. Na tej prestiżowej liście znajdują się obecnie 93 miejsca z całego świata, wpisane ze względu na wypełnianie kryterium (VIII), odnoszącego się wprost do dziedzictwa Ziemi.

Stanowiska geologiczne prezentują zróżnicowaną tematykę naukową, kulturową oraz wartości estetyczne. Można zatem wyróżnić wiele ich typów, nawiązujących do różnych aspektów nauki i kultury. W klasyfikacji stosowanej w europejskim programie Geosites, realizowanym w latach 1995-2000, wyróżniono następujące typy stanowisk (Wimbledon i in., 1999; Alexandrowicz, 2003): A - paleontologiczne (ryc. 1 - patrz str. 65), B - geomorfologiczne (ryc. 2 - patrz str. 65 i ryc. 3), C-paleośrodowiskowe (ryc. 1), D - petrograficzne, E - stratygraficzne (ryc. 1), F - mineralogiczne, $\mathrm{G}$ - tektoniczno-strukturalne (ryc. 3, 4), H - złożowo-górnicze (ryc. 5) i K - kosmologiczne. W tym podziale brakuje jednak na przykład stanowisk hydrogeologicznych, między innymi bardzo ważnych edukacyjnie źródeł (ryc. 6;
Baścik i in., 2011). Podobne grupy stanowisk były wyróżniane we wcześniejszych polskich publikacjach dotyczących ochrony konserwatorskiej abiotycznych elementów przyrody (Birkenmajer, 1965; Alexandrowicz, 1978). Najobszerniejsze listy wymieniają nawet ponad dwadzieścia typów stanowisk geologicznych, definiowanych ze względu na temat przewodni (np. Ruban, Kuo, 2010). Oczywiście wiele stanowisk łączy w sobie różne wartości naukowe (geologiczne, geomorfologiczne, historyczno-ekonomiczne), dlatego też reprezentują one kilka typów jednocześnie.

Stan ochrony prawnej dziedzictwa geologicznego w Polsce był wielokrotnie przedstawiany (Alexandrowicz i in., 1975, 1992; Alexandrowicz, Poprawa, 2000; Gawlikowska, 2000; Wróblewski, 2000). Obecnie na terenie Polski jest chronionych ponad 1600 pomników przyrody nieożywionej (głazów narzutowych, skałek, jaskiń, źródeł, wodospadów, odsłonięć geologicznych, wzniesień i wąwozów), nieco ponad 120 stanowisk dokumentacyjnych (głównie odsłonięć geologicznych) oraz wiele zespołów przyrodniczo-krajobrazowych z wartościowymi elementami abiotycznymi. Stanowiska geologiczne o wysokich wartościach są chronione w ponad 110 rezerwatach przyrody (nie tylko w rezerwatach przyrody nieożywionej, ale także w rezerwatach krajobrazowych, leśnych, stepowych i florystycznych) oraz wielu parkach narodowych i krajobrazowych

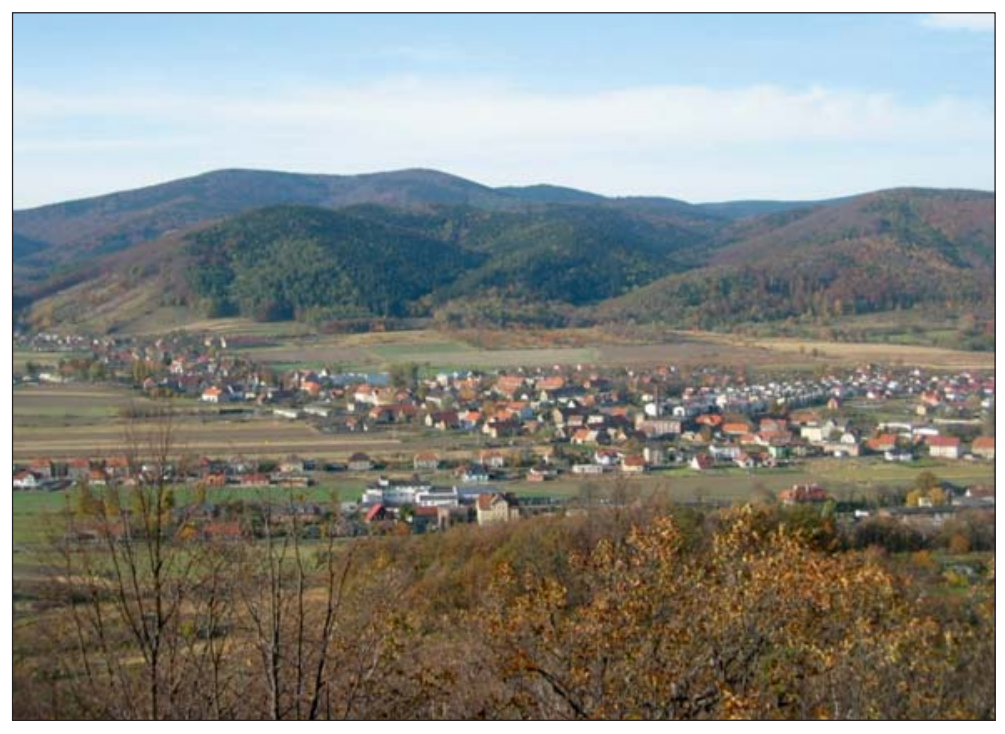

\section{$\leftarrow$}

Ryc. 3. Geostanowisko - punkt widokowy. Tektoniczny próg Sudetów na odcinku Gór Sowich, związany genetycznie z sudeckim uskokiem brzeżnym i rozcięty erozyjnie przez doliny wciosowe, widoczny z wieży widokowej nad Bielawą (Przedgórze Sudeckie). Fot. P. Migoń

Fig. 3. Viewpoint geosite. Fault-generated mountain front of the Sudetes in the Sowie Mountains, related to the activity of the Sudetic Marginal Fault and erosionally dissected by V-shaped valleys, seen from the observation tower above the town of Bielawa (Sudetic Foreland). Photo by P. Migoń

Ryc. 4. Geostanowisko - odsłonięcie struktur tektonicznych. Największe w polskich Karpatach fliszowych odsłonięcie warstw menilitowych w dolinie Wisłoka w Rudawce Rymanowskiej, z dobrze widocznymi fałdami szewronowymi, chronione jako stanowisko dokumentacyjne. Fot. B. Radwanek-Bąk

Fig. 4. Geosite - outcrop of tectonic structures. The largest outcrop of menilite beds in the Polish Flysh Carpathians, Rudawka Rymanowska, Wisłok valley. Chevron folds are well exposed and protected as a documentary site. Photo by B. Radwanek-Bąk
}

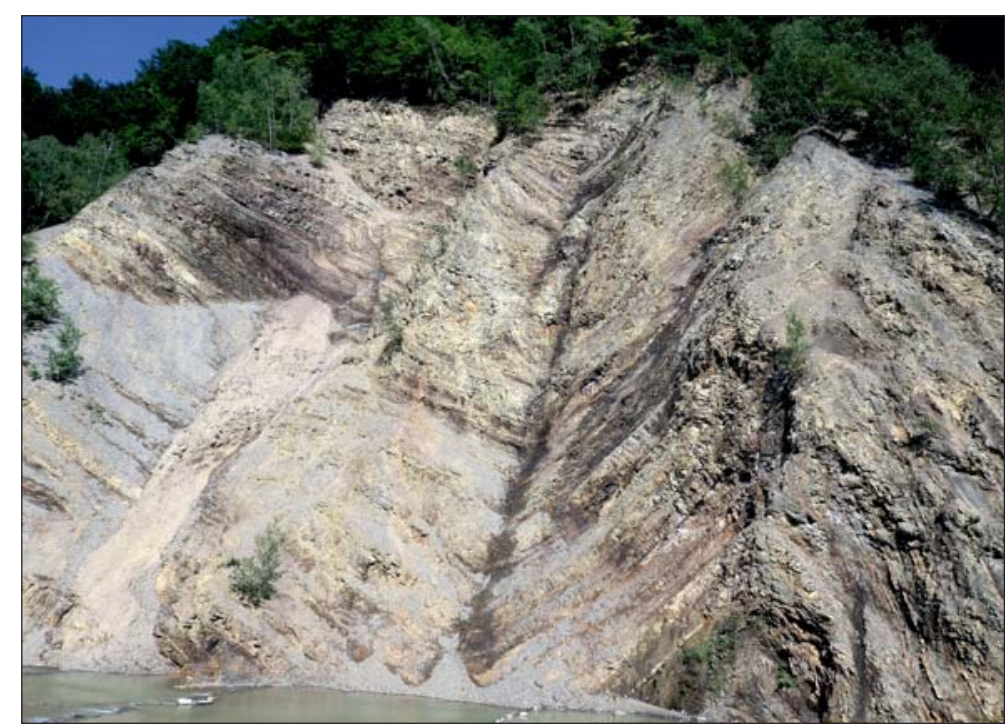




\section{$\longrightarrow$}

Ryc. 5. Geostanowisko związane z dziedzictwem górniczym. Chodnik historycznej podziemnej kopalni kamieni młyńskich i żarnowych produkowanych z mioceńskich piaskowców wapnistych w Senderkach na Roztoczu. Miejsce włączone w sieć obszarów chronionych Natura 2000 jako zimowisko nietoperzy i udokumentowane jako geostanowisko. Fot. J. Urban

Fig. 5. Mining heritage-related geosite. Gallery of the historical mine - a site of millstone production from calcareous sandstone of Miocene age - in the village of Senderki, Roztocze region. The site is included in the Natura 2000 network of protected areas as a bat hibernation site and is a registered geosite. Photo by J. Urban

(Alexandrowicz i in., 2006; Alexandrowicz, 2007, 2008; Słomka, 2012; dane autorów).

Najskuteczniejszym sposobem ochrony dziedzictwa geologicznego w Polsce byłoby upowszechnienie tego pojęcia w naszym języku i jego przeniknięcie do świadomości społecznej, a także wprowadzenie do języka prawnego. Dotyczy to również terminu stanowisko geologiczne (lub geostanowisko). Dotychczas wyrażenie dziedzictwo geologiczne nie pojawiło się w naszym prawodawstwie. W ustawie o ochronie przyrody z 2004 r. oraz przepisach szczegółowych wynikających z tej ustawy (np. regulujących sposób wykonania planów ochrony obszarów chronionych) jego elementy, m.in. stanowiska geologiczne, są określane bardzo różnymi i nieprecyzyjnymi terminami. Brakuje także odniesień do stanowisk geologicznych w ustawie o pla-

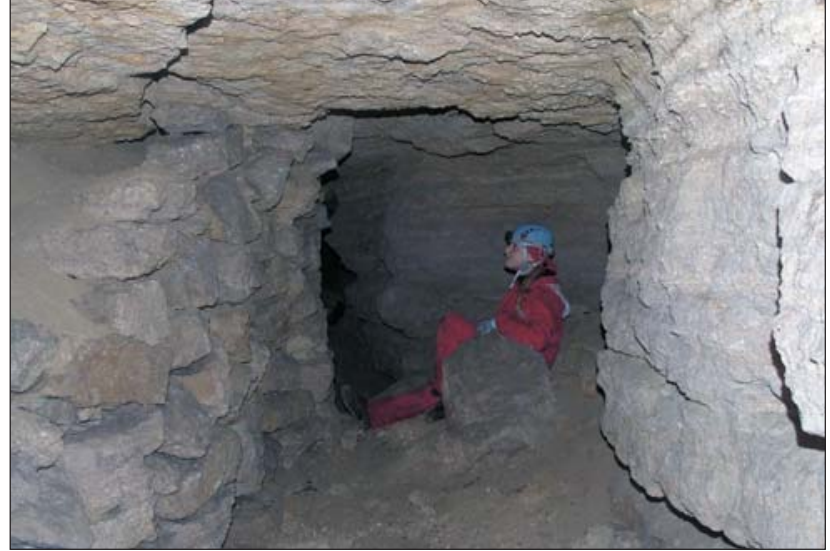

nowaniu i zagospodarowaniu przestrzennym z 2003 r. Ostatnio zaproponowano wprowadzenie ochrony dziedzictwa geologicznego do zakresu zadań państwowej służby geologicznej (Nieć, Radwanek-Bąk, 2019). W sferze społecznej bardzo istotne wydaje się zainteresowanie problemem ochrony dziedzictwa geologicznego członków organizacji pozarządowych, działających w zakresie ekologii i ochrony przyrody, jak również większe uaktywnienie w Polsce międzynarodowych stowarzyszeń i grup naukowych, mających na celu tworzenie podstaw naukowych ochrony tego dziedzictwa, takich jak np. ProGEO (The European Association for the Conservation of the Geological Heritage), mające już w Polsce swoich przedstawicieli.

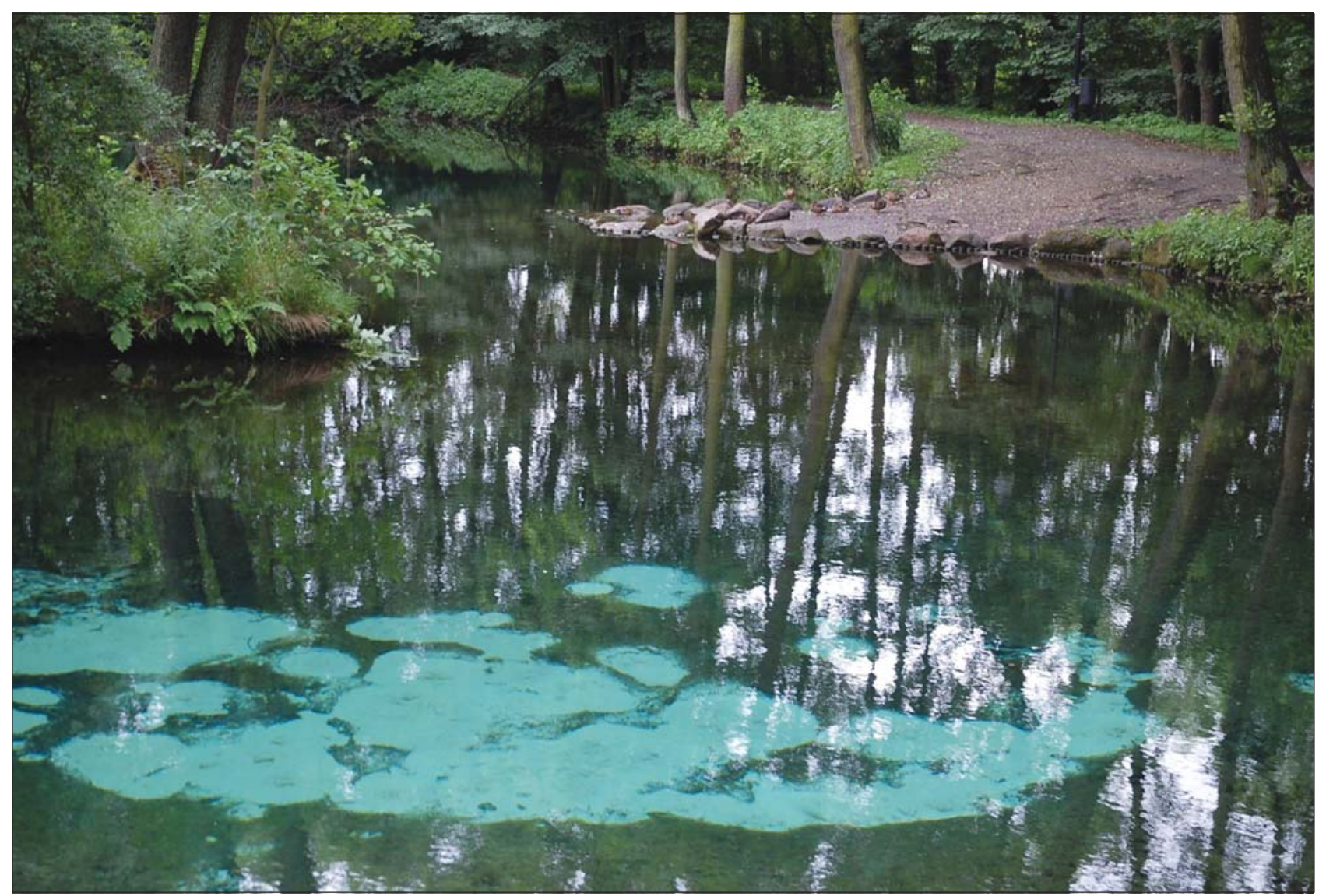

Ryc. 6. Geostanowisko hydrogeologiczne. Niebieskie Źródła koło Tomaszowa Mazowieckiego - wydajne źródła krasowe. Obiekt chroniony jako rezerwat przyrody. Fot. P. Migoń

Fig. 6. Hydrogeological geosite. Niebieskie Źródła (Blue Springs) near the town of Tomaszów Mazowiecki - a cluster of efficient karst springs. The site is protected as a nature reserve. Photo by P. Migoń 
Rolą osób zawodowo związanych z naukami o Ziemi jest $\mathrm{w}$ tej sytuacji promocja dziedzictwa geologicznego poprzez uzasadnianie jego znaczenia oraz konieczności ochrony przedstawicielom władz różnego szczebla, a także prezentowanie stanowisk geologicznych społeczeństwu. Szeroka ich prezentacja i promocja ich ochrony może się odbywać poprzez publikacje popularnonaukowe, wszelkiego rodzaju media elektroniczne (m.in. portale społecznościowe, internetowe bazy danych, tematyczne aplikacje) lub bezpośrednio, podczas wycieczek i spacerów z lokalnymi mieszkańcami, uczniami czy grupami turystycznymi.

Cykl artykułów opisujących stanowiska geologiczne na terenie Polski, zaproponowany przez Redakcję Przegladu Geologicznego, ma na celu pokazanie ich właśnie jako elementów naszego dziedzictwa, które należy odpowiednio zwaloryzować, objąć prawną i praktyczną ochroną oraz właściwie wykorzystać naukowo i edukacyjnie. Sądzimy, że - mimo wielu już publikacji dotyczących stanowisk geologicznych różnych regionów naszego kraju - cykl artykułów o stanowiskach geologicznych, prezentowany w tym czasopiśmie, znajdzie szerokie grono odbiorców wśród specjalistów nauk o Ziemi, zainteresowanych dziedzictwem geologicznym przedstawicieli organów i służb ochrony przyrody, a także działających w tym zakresie członków organizacji pozarządowych, wskazując im cel oraz metody ochrony tego dziedzictwa.

\section{LITERATURA}

ALEXANDROWICZ Z. 1978 - Ochrona zabytków przyrody nieożywionej. [W:] Michajłow W., Zabierowski K. (red.), Ochrona i kształtowanie środowiska przyrodniczego. PWN, Kraków: 385-426.

ALEXANDROWICZ Z. 2003 - Ochrona dziedzictwa geologicznego Polsk w koncepcji europejskiej sieci geostanowisk. Prz. Geol., 51 (3): 224-230.

ALEXANDROWICZ Z. 2006 - Framework of European geosites in Poland. Nature Conserv., 62: 63-87.

ALEXANDROWICZ Z. 2007 - Geoochrona w ujęciu narodowym, europejskim i światowym (ze szczególnym uwzględnieniem Polski). Biul. Państw. Inst. Geol., 425: 19-26.

ALEXANDROWICZ Z. 2008 - Geoconservation in Poland for progresses of long-lasting development. Prz. Geol. 56 (8/1): 579-583.

ALEXANDROWICZ Z., POPRAWA D. (red.) 2000 - Ochrona georóżnorodności w polskich Karpatach. Państw. Inst. Geol.

ALEXANDROWICZ Z., DRZAŁ M., KOZŁOWSKI S. 1975 - Katalog rezerwatów i pomników przyrody nieożywionej w Polsce. Studia Naturae 26, PWN, Kraków.

ALEXANDROWICZ Z., KOZŁOWSKI S., URBAN J. 2006 Geodiversity assessment in Poland applied to the geoconservation framework (Abstract). [W:] ProGEO Symp. Safeguarding our geological heritage, Volume of abstract, Kyiv: 7-8.

ALEXANDROWICZ Z., KUĆMIERZ A., URBAN J., OTESKA-BUDZYN J. 1992 - Waloryzacja przyrody nieożywionej obszarów i obiektów chronionych w Polsce. Państw. Inst. Geol.

BAŚCIK M., CHEŁMICKI W., URBAN J. 2009 - Geoconservation of springs in Poland. Episodes, 32 (3): 177-185.

BIRKENMAJER K. 1965 - Ochrona przyrody nieożywionej. [W:] Szafer W. (red.), Ochrona przyrody i jej zasobów - problemy i metody, t. I. Zakł. Ochrony Przyr. PAN, Kraków: 242-260.

BRILHA J. 2018 - Chapter 4. Geoheritage: inventories and evaluation, [W:] Reynard E., Brilha J. (red.), Geoheritage. Assessment, protection and management. Elsevier Inc., Amsterdam: 69-83.

BRILHA J., GRAY M., PEREIRA D.I., PEREIRA P. 2018 - Geodiversity: an integrative review as a contribution to the sustainable management of the whole of nature. Environmental Science and Policy, 86: 19-28. BROCX M., SEMENIUK V. 2007 - Geoheritage and geoconservation history, definition, scope and scale. J. Royal Soc. of Western Australia, 90: 53-87.

CHYBIORZ R., KOWALSKA M. 2017 - Inwentaryzacja i ocena atrakcyjności geostanowisk województwa śląskiego. Prz. Geol., 65 (6): 365-374. CHYBIORZ R., KRAWCZYŃSKI W., SZELĘG E., TYC A. 2015 - Dziedzictwo geologiczne i geomorfologiczne. [W:] Tokarska-Guzik B., Chybiorz R., Parusel J.B. (red.), Baza danych przestrzennych w zarządzaniu zasobami środowiska przyrodniczego województwa śląskiego. Uniw. Śl. Katowice: 9-20.
CROFTS R., GORDON J.E., BRILHA J., GRAY M., GUNN J., LARWOOD J., SANTUCCI V.L., TORMEY D., WORBOYS G.L. $2020-$ Guidelines for geoconservation in protected and conserved areas. Best Practice Protected Area Guidelines Series 31. Gland, Switzerland: IUCN.

DINGWALL P., WEIGHEL T., BADMAN T. 2005 - Geological worlds heritage: a global framework. IUCN: whc.unesco.org.document. activity-504-1.pdf

GAWLIKOWSKA E. 2000 - Ochrona georóżnorodności na Dolnym Śląsku. Państw. Inst. Geol.

GRAY M. 2013 - Geodiversity. Valuing and conserving abiotic nature. J. Wiley\&Sons Ltd, Chichester.

KASPRZAK K., SKOCZYLAS J. 1994 - Ochrona zasobów przyrody nieożywionej - przeszłość, teraźniejszość, przyszłość. Prz. Geol., 42 (3): $169-173$.

KOZŁOWSKI S., MIGASZEWSKI Z., GAŁUSZKA A. 2004 - Znaczenie georóżnorodności w holistycznej wizji przyrody. Prz. Geol., 52 (4): 291-294.

MARTINI G. (red.) 1994 - Proceedings of the $1^{\text {st }}$ International Symposium on the Conservation of our Geological Heritage. Digne les Bains, France, 11-16 June 1991. Mémoires de la Société Géologique de France, 165: 1-266.

MIGOŃ P. 2008 - Geomorfologia w ochronie dziedzictwa przyrodniczego i kulturowego - wymiar globalny i lokalny. Landform Analysis, 9: 25-29. MIGOŃ P. 2012 - Geoturystyka. Wyd. Nauk. PWN, Warszawa.

NIEĆ M., RADWANEK-BĄK B. 2019 - Pogląd na zakres działań i organizacje państwowej służby geologicznej w polityce surowcowej państwa. Prz. Geol., 67 (12): 968-972.

REYNARD E. 2004 - Geosite. [W:] Goudie A.S. (red.), Encyclopedia of geomorphology, vol. 1. Rotledge, London: 440.

RUBAN D., KUO I.-L. 2010 - Essentials of geological heritage site (geosite) management: a conceptual assessment of interests and conflicts. Natura Nascosta, 41: 16-31.

RUBINOWSKI Z. 1994 - Zadania geologii w praktycznej realizacji współczesnej ochrony przyrody nieożywionej w Polsce. Prz. Geol., 42 (3): 166-168.

SŁOMKA T. (red.) 2012 - Katalog obiektów geoturystycznych w obrębie pomników i rezerwatów przyrody nieożywionej. AGH Akademia Górniczo-Hutnicza, Kraków.

SOLON J., ROO-ZIELIŃSKA E., AFFEK A., KOWALSKA A., KRUCZKOWSKA B., WOLSKI J., DEGÓRSKI M., GRABIŃSKA B., KOŁACZKOWSKA E., REGULSKA E., ZAWISKA I. 2017 - Świadczenia ekosystemowe w krajobrazie młodoglacjalnym. Ocena potencjału i wykorzystania. Inst. Geogr. Przestrz. Zagosp. PAN. Wyd. Akademickie SEDNO, Warszawa.

URBAN J., RADWANEK-BĄK B., MARGIELEWSKI W. 2020 w dru$\mathrm{ku}$-Ochrona dziedzictwa geologicznego w Polsce - tradycje, teraźniejszość i wyzwania przyszłości. [W:] Dąbrowski P. (red.), Zaczęło się od Tatr. Centr. Ośr. Turystyki Górskiej PTTK, Kraków.

WAROWNA J., MIGOŃ P., KOŁODYŃSKA-GAWRYSIUK R, KIEBAŁA A., ZGŁOBICKI W. 2013 - Geomorphosites in Poland - the role played by the Central Register of Geosites. Landform Analysis, 22: 117-124.

WIMBLEDON W.A.P., ANDERSEN S., CLEAL C.J., COWIE J.W., ERIKSTAD L., GONGRIJP G.P., JOHANSSON C.E., KARIS L.O., SUOMINEN V. 1999 - Geological World Heritage: GEOSITES - a global comparative site inventory to enable prioritisation for conservation. Memorie Descrittive della Carta Geologica d' Italia, 54: 45-60.

WIMBLEDON W.A.P., ISHCHENKO A.A., GERASIMENKO N.P., DRANDAKI I., KARIS L.O., SUOMINEN V., JOHANSSON C.E., FREDEN C. 2001 - Geosites - an IUGS initiative: science supported by conservation. [W:] Barettino D., Wimbledon W.A.P., Gallego E. (red.), Geological heritage: its conservation and management. III Intern. Symposium ProGEO, Madrid (Spain): 69-95.

WIMBLEDON W.A.P., SMITH-MEYER S. (red.) 2012 - Geoheritage in Europe and its conservation. ProGEO, Oslo.

WRÓBLEWSKI T. 2000 - Ochrona georóżnorodności w regionie świętokrzyskim. Państw. Inst. Geol.

WYK DE VRIES B., BYRNE P., DELCAMP A., EINARSON P., GÖĞÜS O., GUILBAUD M-N., HAGOS M., HARANGI S., JERRAM D., MATENCO L., RAPPRICH V., ROSE W., VYE E. 2018 - A global framework for the Earth: putting geological sciences in context. Global and Planetary Change, 171: 293-321.

ZWOLIŃSKI Z., NAJWER A., GIARDINO M. 2018 - Chapter 2. Methods of assessing geodiversity [W:] Reynard E., Brilha J. (red.), Geoheritage. Assessment, protection and management. Elsevier Inc. Amsterdam, 27: 69-83.

Praca wpłynęła do redakcji 1.12.2020 r.

Akceptowano do druku 5.01.2021 r. 


\section{Dziedzictwo geologiczne (patrz str. 16)}

\section{Geological heritage (see p. 16)}

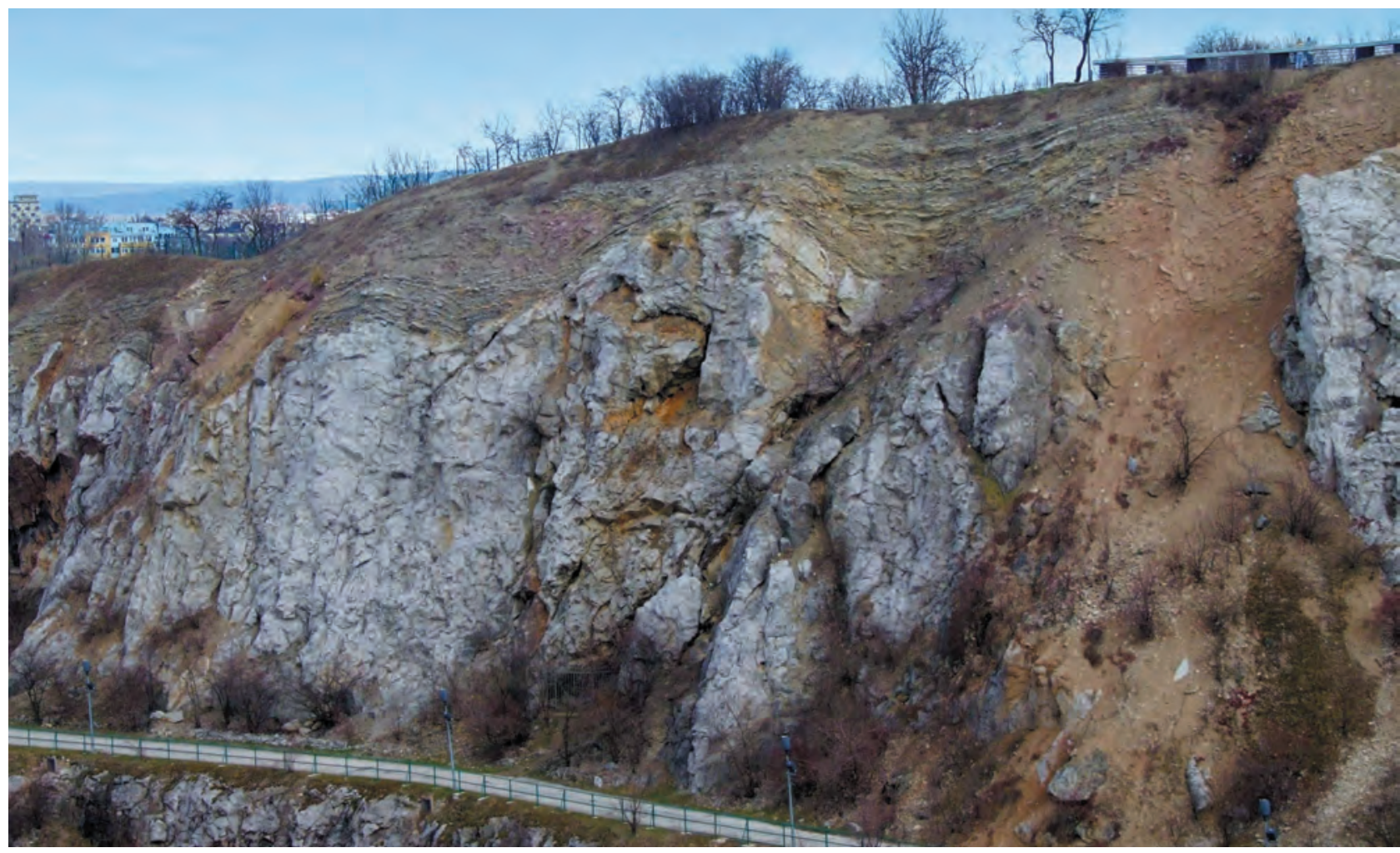

Ryc. 1. Geostanowisko - profil geologiczny i stanowisko paleontologiczno-paleośrodowiskowe. Wschodnia ściana dawnego kamieniołomu na Kadzielni, stanowiącego obecnie Park Miejski w Kielcach ze ścieżką geoturystyczną. W ścianie odsłania się profil utworów węglanowych górnego dewonu, w którym jest widoczna wyraźna zmiana litologiczna, odzwierciedlająca zmianę warunków sedymentacyjnych Fig. 1. Geosite - geological sequence and palaeontological-palaeoenvironmental site. Eastern face of the Kadzielnia abandoned quarry, currently Kielce City Park with a geotouristic trail. The quarry face reveals a geological sequence of Upper Devonian carbonate rocks in which the evident lithological change reflects diverse sedimentological conditions

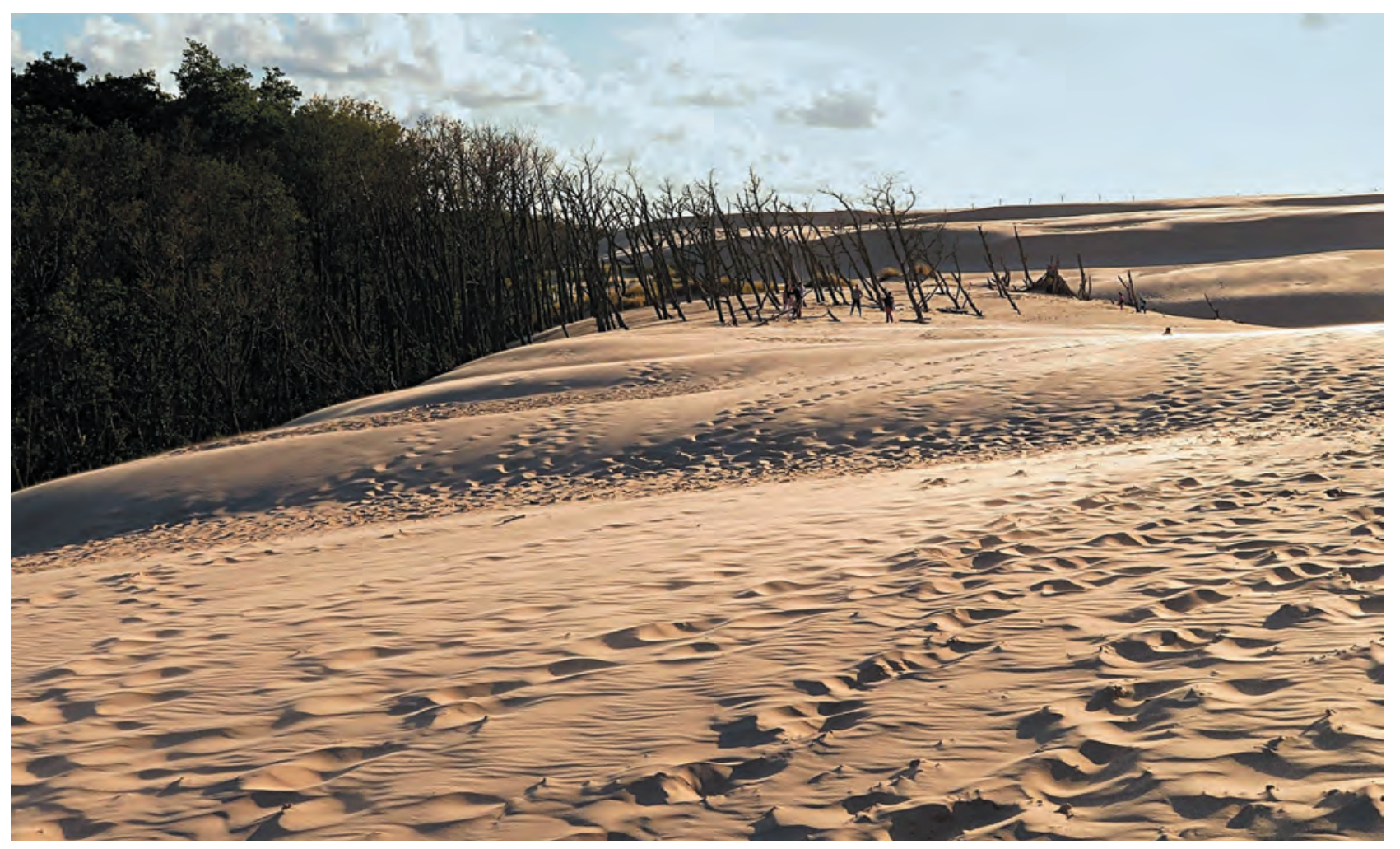

Ryc. 2. Geostanowisko geomorfologiczne. Ruchome wydmy w Słowińskim Parku Narodowym będące przykładem rzeźby eolicznej i współczesnych procesów geomorfologicznych. Obie fot. J. Urban

Fig. 2. Geomorphological geosite. Active dunes in the Słowiński National Park are examples of aeolian landforms and ongoing geomorphological processes. Both photos by J. Urban 